\title{
Changes in the Mineralisation of Nutrients and Sunflower Biomass in Soil Irrigated with Water from Oil Exploration in a Semi-Arid Environment
}

\author{
Adervan Fernandes Sousa ${ }^{\mathrm{a}}$, Lindbergue Araújo Crisostomo ${ }^{\mathrm{b}}$, Olmar Baller Weber ${ }^{\mathrm{b}}$, \\ Maria Eugenia Ortiz Escobar ${ }^{c}$, Teógenes Senna de Oliveira ${ }^{\mathrm{d}}$
}

\begin{abstract}
${ }^{a}$ Universidade Estadual do Ceará/FAEC, Rua José Furtado s/n, Crateús, Ceará, Brazil.
bEmbrapa Agroindústria Tropical, Rua Dra. Sara Mesquita, 2270, Pici, 60511-110, Fortaleza, Ceará, Brazil.

${ }^{c}$ Departmentof Soil Science, Universidade Federal do Ceará, Block 807 s/n, Campus do Pici, Fortaleza, Ceará, Brazil. ${ }^{d}$ Department for Soils, Universidade Federalde Viçosa, Av. Peter Henry Rolfs s/n, Campus Universitário, CEP 36570900 , Viçosa, Minais Gerais, Brazil.
\end{abstract}

\begin{abstract}
Wastewater from oil fields may be an option for irrigation, especially in regions which have low rainfall with high variability. The aim was to evaluate the composition and decomposition of shoot biomass from sunflower plants irrigated with water from oil wells, which had been subjected to filtering (FPW) and reverse osmosis (OPW), using groundwater (UGW) as a reference. Two tests were then carried out to evaluate decomposition of the residue. In the first test, residues produced with FPW, OPW and UGW were incubated in soil and irrigated with groundwater $(U G W)$. In the second test, residues from plants irrigated with $U G W$ were also incubated, but irrigated with FPW, OPW and $U G W$. Significant differences were seen in the levels of $\mathrm{Na}, \mathrm{Mg}$ and lignin in the residues with the use of FPW, showing greater levels for $\mathrm{Na}$, and lower levels for $\mathrm{Mg}$ and lignin. The loss in biomass of the incubated residues was not significant in either test; this was not seen in the $\mathrm{Mg}$ e $N$ with smaller losses than the biomass, or the Na, $\mathrm{K}$ e $S$ with greater losses, especially when produced with FPW and OPW respectively. In the residue produced with $U G W$, differences were identified for $\mathrm{Ca}$ and $\mathrm{Na}$, with the order of losses for type of water being $U G W=F P W>$ $O P W$ and $O P W=U G W>F P W$ respectively. Irrigation using water from oil extraction alters the chemical characteristics of the soil and the composition of cultivated plants at a level sufficient to influence the rate of decomposition of the organic residue.
\end{abstract}

Keywords- Sunflower residue, Produced water, Wastewater management, Mineralisation, Substrate quality.

\section{INTRODUCTION}

The use of wastewater has become an acceptable agronomic practice $[1,2]$, being of considerable interest to the oil industry as it removes the problem of disposing of produced water, helps to conserve water resources, and improves nutrient recycling [3, 4]. However, the produced water which is generated in oil wells, may contain heavy metals, organic and inorganic compounds [5], salts, and additives used during extraction, such as anticorrosives and biocides [6], which can pose risks to the environment. A large volume of produced water is generated in an oil field, and may be an option in the irrigation of crops grown for fuel. Irrigation with produced water can be particularly effective in areas with poor rainfall distribution and a shortage of drinking water. However, this can alter the chemical properties of the soil [3, 7-9] and as a consequence, the chemical composition of plants [7, 9-11].

The decomposition of organic matter is an important stage in nutrient cycles, and is affected by the chemical composition of the plant residue, as nutrient levels and the energy available to decomposers determine the efficiency of the mineralisation of organic residues [12, 13]. Studies into decomposition have shown a reduction in the mineralisation of organic residue for levels of $\mathrm{Mg}$, while the opposite was seen for $\mathrm{Ca}[14]$ and $\mathrm{P}[15,16]$. Talbot and Treseder [17] reported that initial levels of $\mathrm{N}$ in organic residue increased mineralisation, while Birouste et al. [15] were unable to confirm this observation. On the other hand, initial concentrations of lignin were seen to negatively influence losses in biomass $[17,18]$ but had no effect on the release of $\mathrm{N}$ [17]. 
Changes in soil properties, in particular increases in the concentration of toxic minerals, can also affect the decomposition of organic residue, since they affect the structure and activity of microbial communities in the soil $[19,20]$. The physical and chemical properties of the soil are known to influence microbial communities [21]. This effect can be modified by salinity, sodicity and alkalinity, which can reduce biomass and microbial activity [22], and inhibit respiration [23].

It is probable that irrigation with produced water from oil extraction causes changes in the chemical properties of the soil and the chemical composition of plants. Information is available on the effects of chemical composition, both of the soil and of organic residue, on rates of decomposition [17, 18, 24], but no study has evaluated the effects of water quality on the chemical composition of plants, and the consequent changes in the mineralisation of nutrients and the decomposition of biomass, cellulose and lignin. Crop residues are important for the nutrient-cycling process in systems of agricultural production; it is therefore essential to evaluate any possible changes in the decomposition of plants irrigated with produced water. In the present study, decomposition rates for the residues of sunflower shoots (Helianthus annuus L. cv. BRS 321), irrigated with produced water subjected to filtration and reverse osmosis, and with groundwater captured in the Açu aquifer, were studied. The aim was to determine whether produced water submitted to two different treatments (filtering and reverse osmosis) alters the chemical characteristics of plants and influences decomposition of organic residue.

\section{MATERIALS AND METHODS}

The study area was an experimental field of the Brazilian oil company, Petrobras, located on the Belém Farm, in Aracati, in the State of Ceará, in the semi-arid region of

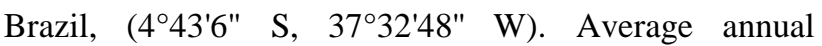
temperature and rainfall in the region are $28^{\circ} \mathrm{C}$ and 949.2 $\mathrm{mm}$ respectively, with the greatest concentration from March to May. Profiles were described for the study area, and the class of soil identified as a Haplic Arenosol [25]. Two crop cycles of the sunflower Helianthus annuus L., cv. BRS 321 were conducted in an experimental design of randomised blocks, with three replications in plots of $400 \mathrm{~m}^{2}$. In the first growing period, the crop cycle ran from July to Octoberof 2012, and in the second, from March to June of 2013. The plots were irrigated with wastewater from oil production, which were subjected to two pre-treatments after extraction of the oil. For the first pre-treatment, the water was initially filtered through sand filters, and then passed through a cation-resin filter to remove residue of the caustic soda used in the oil-water separation process (FPW). In the second pre-treatment, the FPW was subjected to nanofiltration and reverse osmosis (OPW). The control treatment used groundwater captured from wells at a depth of $250 \mathrm{~m}$ in the Açu aquifer (UGW). The chemical characteristics of the irrigation water are shown in Table 1.

Table.1: Principal chemical characteristics of the waters used for irrigation and the soil after irrigation.

\begin{tabular}{|c|c|c|c|c|c|c|c|c|c|c|}
\hline \multirow{3}{*}{\multicolumn{2}{|c|}{ Characteristic }} & \multicolumn{6}{|c|}{ Type of water } & \multicolumn{3}{|c|}{ Soil $^{*}(0.0-0.1 \mathrm{~m})$} \\
\hline & & \multicolumn{2}{|c|}{ OPW } & \multicolumn{2}{|c|}{ FPW } & \multicolumn{2}{|c|}{ UGW } & \multirow{2}{*}{$\frac{\text { OPW }}{n=3}$} & \multirow{2}{*}{$\begin{array}{c}\text { FPW } \\
n=3\end{array}$} & \multirow{2}{*}{$\frac{\mathrm{UGW}}{\mathrm{n}=3}$} \\
\hline & & $\mathrm{n}=4^{\dagger}$ & $\mathrm{n}=6^{\dagger \dagger}$ & $\mathrm{n}=4^{\dagger}$ & $\mathrm{n}=6^{\dagger \dagger}$ & $\mathrm{n}=4^{\dagger}$ & $n=6^{\dagger \dagger}$ & & & \\
\hline $\mathrm{EC}$ & $\mathrm{dS} \mathrm{m}^{-1}$ & 0.62 & 0.38 & 2.51 & 1.95 & 0.65 & 0.66 & 2.05 & 5.34 & 1.96 \\
\hline $\mathrm{pH}$ & - & 7.35 & 7.52 & 8.84 & 9.21 & 8.24 & 8.34 & 8.15 & 8.53 & 8.53 \\
\hline $\mathrm{Ca}^{2+}$ & & 0.01 & 0.11 & 0.18 & 0.11 & 0.21 & 0.21 & 4.50 & 2.31 & 2.66 \\
\hline $\mathrm{Mg}^{2+}$ & & 0.03 & 0.07 & 0.65 & 0.16 & 0.10 & 0.11 & 4.26 & 1.98 & 2.20 \\
\hline $\mathrm{Na}^{+}$ & & 3.75 & 2.95 & 24.15 & 18.15 & 7.10 & 6.23 & 7.80 & 40.47 & 14.53 \\
\hline $\mathrm{K}^{+}$ & $\mathrm{mmol}_{\mathrm{c}} \mathrm{L}^{-1}$ & 0.11 & 0.05 & 0.68 & 0.09 & 0.09 & 0.08 & 3.63 & 1.77 & 0.82 \\
\hline $\mathrm{Cl}^{+}$ & & 2.89 & 1.21 & 13.74 & 12.7 & 2.06 & 2.41 & 24.10 & 59.45 & 20.28 \\
\hline $\mathrm{CO}_{3}{ }^{2-}$ & & 0.00 & 0.07 & 1.73 & 1.07 & 0.5 & 0.17 & - & - & - \\
\hline $\mathrm{HCO}_{3}{ }^{-}$ & & 0.59 & 1.95 & 3.00 & 3.55 & 3.00 & 3.74 & 3.90 & 5.50 & 4.60 \\
\hline
\end{tabular}

$\dagger$ first growing period, when the residue was obtained, ${ }^{\dagger}$ second growing period, when the residue was incubated; ${ }^{\star}$ Soil chemical attributes at the time of incubation and decomposition of the residue. 
A drip irrigation system was used, with the emitters distributed along the crop rows, at a spacing of $0.30 \mathrm{~m}$ and with a flow of $1 \mathrm{~L} \mathrm{~h}^{-1}$. In order to meet the water requirement of the crop, the amount of water applied to the soil was up to $4.5 \mathrm{~L} \mathrm{~m}^{-2}$ day $^{-1}$, calculated based on the evapotranspiration of the sunflower crop and water loss through drainage, employing columns of mini-lysimeters in the experimental plots. During the first growing period, on average $271 \mathrm{~L} \mathrm{~m}^{-2} \mathrm{OPW}, 365 \mathrm{~L} \mathrm{~m}^{-2} \mathrm{FPW}$, and $393 \mathrm{~L} \mathrm{~m}^{-}$ ${ }^{2} \mathrm{UGW}$ were applied for plant irrigation. During thesecond period, $395 \mathrm{~L} \mathrm{~m}^{-2} \mathrm{OPW}, 353 \mathrm{~L} \mathrm{~m}^{-2} \mathrm{FPW}$, and $260 \mathrm{~L} \mathrm{~m}^{-2}$ UGW were applied. During the experiment, the maximum mean temperature was $33^{\circ} \mathrm{C}$, with a minimumof $23^{\circ} \mathrm{C}$, and a precipitationof $483 \mathrm{~mm}\left(\mathrm{~L} \mathrm{~m}^{-2}\right)$ in the second growing period.Based on the soil analysis prior to planting, it was necessary to correct the soil to meet the nutritional requirements of the crop. The soil was therefore corrected with organic fertiliser, $7.5 \mathrm{~kg} / \mathrm{lm}$ before the first crop, and $2.5 \mathrm{~kg} / \mathrm{lm}$ before the second crop. Also, in each cycle, doses of $80 \mathrm{~kg} / \mathrm{ha} \quad \mathrm{P}_{2} \mathrm{O}_{5}$ and $40 \mathrm{~kg} / \mathrm{ha} \quad \mathrm{K}_{2} \mathrm{O}$ were incorporated into the soil before planting, as well as 50 $\mathrm{kg} / \mathrm{ha} \mathrm{N}$ close to the flowering stage.

Samples of shoot residue from sunflower plants produced in the first crop cycle, and irrigated with OPW, FPW, and UGW, were incubated with UGW in the irrigated plots (Test 1); and plant residue from plots where only UGW was used was incubated in the plots irrigated with OPW, FPW and UGW (Test 2).

For incubation, $30 \mathrm{~g}$ of air-dried shoot residue with a maximum size of $0.05 \mathrm{~m}$, were placed into $0.14 \mathrm{~m}$ by 0.15 $\mathrm{m}$ nylon bags of anti-aphid mesh [26] and arranged horizontally in the soil at a depth of 0.05 to $0.10 \mathrm{~m}$, near the drippers, avoiding direct contact with the plant roots. The chemical characteristics of the 0 to $0.1 \mathrm{~m}$ layer of soil (which corresponds to the depth of the incubated residue) after irrigation with the different types of water, are shown in Table 1. The bags were collected after 14, 28, 41,55 and 69 days of incubation, and the residue dried at $65^{\circ} \mathrm{C}$, weighed to determine the biomass, and stored for further chemical analysis. Sub-samples of the crop residue were used to determine the dry weight $\left(65^{\circ} \mathrm{C}\right)$ and chemical characteristics at the start of the experiment $(\mathrm{t}=$ 0 ). For each trial, 45 nylon bags containing residue were incubated in the soil, considering three treatments (OPW, OPF and UGW), five collection periods (14, 28, 41, 55 and 69 days of incubation) and three replications $(n=3)$. The collected residue was submitted to nitro-perchloric digestion (3:1 v/v) and the levels of $\mathrm{Ca}$ and $\mathrm{Mg}$ determined by atomic absorption spectrophotometry (Analyst 400, PerkinElmer), the $\mathrm{Na}$ and $\mathrm{K}$ content was determined by flame photometry (DM-62, Digimed), and $\mathrm{S}$ and $\mathrm{P}$ determined using spectrophotometry (Femto 600 Plus). Levels of $\mathrm{N}^{-\mathrm{NH}_{4}}$ were determined by Kjeldahl distillation [27], and TOC was quantified by wet digestion with potassium dichromate and $\mathrm{H}_{2} \mathrm{SO}_{4}$ while heating [28]. Lignin and cellulose levels were also determined, using the method of acid detergent fibre (ADF) [29]. All the levels were calculated by multiplying the above concentrations by the weight of the collected residue.

At the end of the 69 day incubation period, losses were estimated for the biomass, minerals, lignin and cellulose for each situation under study, the half-life $(t)$ for each of these being determined with the equation $t=\ln (2) / k$ [30], where $\mathrm{k}$ is the decay constant obtained from the equation $\mathrm{Xt}-\mathrm{X} 0 . \mathrm{e}^{\mathrm{KT}}$ [26].

The data were subjected to the Shapiro-Wilk test for normality, and Bartlett's test for the homogeneity of variances, to verify that the assumptions of the variance analyses were met. After noting the normal distribution of the variables, analysis of variance (ANOVA) was used to determine the statistical differences $(\mathrm{P}<0.05)$ between the mean values for the loss of biomass, nutrients $(\mathrm{Ca}, \mathrm{Mg}$, $\mathrm{Na}, \mathrm{K}, \mathrm{S}, \mathrm{P}$, and $\mathrm{N}$ ), C, cellulose and lignin at the end of the 69 day incubation period. Mean values for data displaying any variation were compared by Tukey's test at a level of $5 \%$.

To identify the relationship between the chemical characteristics of the residue and the loss of biomass, nutrients, lignin and cellulose, multivariate analysis of variance (MANOVA) was performed. To identify which variables (chemical characteristics of the residue) were more important in controlling decomposition, the value for Wilks's lambda was calculated; this allows evaluation, for each variable, of the statistical differences for the mean values between groups. The value for Wilks's lambda varies between 0 and 1; the smaller this value, the greater the discriminatory power between sets of variables. Due to interference from the chemical composition of the residue, and the combination and proportions of the different constituents of the decomposing material, the predictor variables used in the model were the initial values for $\mathrm{Ca}, \mathrm{N}, \mathrm{P}, \mathrm{K}, \mathrm{Na}, \mathrm{S}, \mathrm{Mg}$, $\mathrm{C}$, lignin and cellulose, and the ratios of $\mathrm{C}: \mathrm{N}$, cellulose:Ca, cellulose:N, cellulose:Pcellulose:K, cellulose:Na, cellulose:S, cellulose:Mg, lignin:Ca, lignin:N, lignin:P, lignin:K, lignin: $\mathrm{Na}$ and lignin:Mg. The response variables were the weight-loss percentage $(\%)$ for $\mathrm{Ca}, \mathrm{Mg}, \mathrm{Na}, \mathrm{N}, \mathrm{P}, \mathrm{K}, \mathrm{S}, \mathrm{C}$, cellulose, lignin and biomass in organic residue seen at the end of the incubation period (69 days). Statistical analysis was carried out using the R software [31].

\section{RESULTS}

\subsection{Chemical composition of the plant residue}

The nutrient concentrations and compounds from the biomass of the sunflower shoots exhibited distinct 
behaviours when irrigated with the different types of water. Significant differences $(\mathrm{P}<0.05)$ were found in the levels of $\mathrm{Na}, \mathrm{Mg}$ and lignin, with different behaviour when using FPW, the highest levels being seen for $\mathrm{Na}$, while $\mathrm{Mg}$ and lignin displayed the lowest values. $\mathrm{S}$ and $\mathrm{P}$ were significantly lower, while lignin levels were higher compared to UGW when OPW was used. For the other elements and compounds ( $\mathrm{Ca}, \mathrm{K}, \mathrm{N}, \mathrm{C}$ and cellulose) there was no effect from the different types of water used, and no significant statistical differences were noted $(\mathrm{P}<0.05)$ (Table 2).

Table.2: Chemical composition of sunflower shoot residues irrigated with reverse-osmosis produced water (OPW), filtered produced water $(F P W)$ and underground water $(U G W)$.

\begin{tabular}{ccccccccccc}
\hline Type of & \multicolumn{8}{c}{ Chemical composition, $\mathrm{g} \mathrm{kg}^{-1}$} \\
\cline { 2 - 11 } Water & $\mathrm{Ca}$ & $\mathrm{Mg}$ & $\mathrm{Na}$ & $\mathrm{K}$ & $\mathrm{S}$ & $\mathrm{P}$ & $\mathrm{N}$ & $\mathrm{C}$ & Cellulose & Lignin \\
\hline OPW & $29.9 \mathrm{a}$ & $7.0 \mathrm{a}$ & $1.8 \mathrm{~b}$ & $61.9 \mathrm{a}$ & $3.6 \mathrm{~b}$ & $5.2 \mathrm{~b}$ & $10.5 \mathrm{a}$ & $330 \mathrm{a}$ & $34.7 \mathrm{a}$ & $8.0 \mathrm{a}$ \\
FPW & $31.2 \mathrm{a}$ & $5.5 \mathrm{~b}$ & $10.3 \mathrm{a}$ & $63.3 \mathrm{a}$ & $3.8 \mathrm{ab}$ & $5.9 \mathrm{ab}$ & $13.4 \mathrm{a}$ & $294 \mathrm{a}$ & $27.2 \mathrm{a}$ & $6.8 \mathrm{c}$ \\
UGW & $28.1 \mathrm{a}$ & $7.5 \mathrm{a}$ & $2.8 \mathrm{~b}$ & $69.7 \mathrm{a}$ & $4.7 \mathrm{a}$ & $7.7 \mathrm{a}$ & $13.3 \mathrm{a}$ & $308 \mathrm{a}$ & $30.5 \mathrm{a}$ & $7.4 \mathrm{~b}$ \\
\hline
\end{tabular}

Different letters in a column indicate differences between mean values by Tukey's test at 5\% probability.

\subsection{Decomposition of shoot residue from sunflowers} irrigated with different types of water (OPW, FPW and UGW), and incubated in soil irrigated with UGW (Test 1)

The loss percentage for biomass in the residues produced with OPW, FPW and UGW was around 73\%, with no significant difference $(\mathrm{P}<0.05)$ when irrigated with $\mathrm{UGW}$ (Table 3). The same behaviour was also seen for $\mathrm{P}, \mathrm{Ca}, \mathrm{C}$, cellulose and lignin, with overall mean values of 52, 50, 80,80 and $44 \%$ respectively. However, this lack of significance in the differences was not found when evaluating the remaining nutrients, identifying loss percentages which were smaller $(\mathrm{Mg}, \mathrm{P}$ and $\mathrm{N})$ and greater $(\mathrm{Na}, \mathrm{K}$ and $\mathrm{S})$ than the mean for biomass (the main reference, due to being composed of these nutrients), and highlighting the significant statistical differences for the losses of $\mathrm{Na}, \mathrm{Mg}$ and $\mathrm{K}$. The losses were higher for $\mathrm{Na}$ and $\mathrm{Mg}$ when the residues were produced with FPW and OPW respectively. $\mathrm{K}$ had the greatest losses among all the elements studied, on average $98 \%$, with similar losses whether the residue was irrigated with FPW or UGW, these losses being greater than for OPW. S and $\mathrm{N}$ also showed significant losses, but in the following order for the type of water used for irrigation: $\mathrm{UGW}>\mathrm{OPW}=\mathrm{FPW}$ and $\mathrm{FPW}>\mathrm{OPW}=\mathrm{UGW}$ respectively. It was found that generally the greatest losses correspond to the smallest values for half-life. Again, this assertion can be made considering the biomass as reference, as was done with the loss of nutrients. Elements with losses greater than the average seen for biomass, had the lowest values for half-life, while those with smaller losses, had the longest half-life.

There are statistical differences between the values for half-life of the residues when irrigated with the different types of water (Table 3); here, the use of OPW is highlighted, since the half-life was longer using that type of water, as was the case with $\mathrm{Na}, \mathrm{K}, \mathrm{S}, \mathrm{N}$ and the biomass. Some cases showed similar results when using the other types of water (UGW and FPW), however no general trend was seen. In the case of $\mathrm{Mg}$, the use of FPW and UGW gave the greatest value for half-life, while the half-life of $\mathrm{P}$ was greater in residue produced with UGW.

Table.3: Loss of mass and the half-life of biomass and nutrients in differing sunflower shoot residues irrigated with reverseosmosis produced water $(O P W)$, filtered produced water $(F P W)$ and underground water $(U G W)$ after 69 days of incubation in soil irrigated with UGW (Test 1).

\begin{tabular}{cccccccccccc}
\hline \multirow{2}{*}{ Residue } & \multirow{2}{*}{ Biomass } & \multicolumn{10}{c}{ Chemical Constituent } \\
\cline { 3 - 13 } & & $\mathrm{Ca}$ & $\mathrm{Mg}$ & $\mathrm{Na}$ & $\mathrm{K}$ & $\mathrm{S}$ & $\mathrm{P}$ & $\mathrm{N}$ & $\mathrm{C}$ & Celluose & Lignin \\
\hline OPW & $71.9 \mathrm{a}$ & $52 \mathrm{a}$ & $64.8 \mathrm{a}$ & $66.2 \mathrm{~b}$ & $96.6 \mathrm{~b}$ & $73.8 \mathrm{~b}$ & $58.3 \mathrm{a}$ & $52.8 \mathrm{~b}$ & $83 \mathrm{a}$ & $79 \mathrm{a}$ & $41 \mathrm{a}$ \\
FPW & $74.6 \mathrm{a}$ & $49 \mathrm{a}$ & $44.6 \mathrm{~b}$ & $94.0 \mathrm{a}$ & $98.4 \mathrm{a}$ & $78.8 \mathrm{ab}$ & $52.6 \mathrm{a}$ & $66.7 \mathrm{a}$ & $79 \mathrm{a}$ & $82 \mathrm{a}$ & $44 \mathrm{a}$ \\
UGW & $72.8 \mathrm{a}$ & $52 \mathrm{a}$ & $38.9 \mathrm{~b}$ & $77.5 \mathrm{~b}$ & $97.5 \mathrm{a}$ & $82.2^{\mathrm{a}}$ & $45.1 \mathrm{a}$ & $61.7 \mathrm{ab}$ & $81 \mathrm{a}$ & $82 \mathrm{a}$ & $49 \mathrm{a}$
\end{tabular}

Half-life, $t$-days 


$\begin{array}{lllllllllllll}\text { OPW } & 35.3 \mathrm{a} & 66 \mathrm{a} & 49.3 \mathrm{~b} & 29.7 \mathrm{a} & 14.3 \mathrm{a} & 40.3 \mathrm{a} & 49.0 \mathrm{~b} & 44.0 \mathrm{a} & 27 \mathrm{a} & \mathrm{ND} & \text { ND } \\ \text { FPW } & 30.3 \mathrm{~b} & 74 \mathrm{a} & 74.7 \mathrm{a} & 12.3 \mathrm{~b} & 9.0 \mathrm{~b} & 30.3 \mathrm{~b} & 48.0 \mathrm{~b} & 30.7 \mathrm{a} & 30 \mathrm{a} & \text { ND } & \text { ND } \\ \text { UGW } & 31.0 \mathrm{ab} & 65 \mathrm{a} & 77.3 \mathrm{a} & 23.7 \mathrm{a} & 13.0 \mathrm{a} & 29.7 \mathrm{~b} & 69.3 \mathrm{a} & 37.3 \mathrm{a} & 28 \mathrm{a} & \text { ND } & \text { ND }\end{array}$

Different lowercase letters in a column indicate differences between mean values by Tukey's test at 5\% probability. ND $=$ Not determined.

3.3 Decomposition of shoot residue from sunflowers in the area of $U G W$, and incubated in soil irrigated with different types of produced water (OPW, FPW and UGW) (Test 2)

The loss of biomass in this test $(73 \%)$ was similar to the previous test $(72 \%)$ with no statistical differences for type of water used for irrigation in the residue produced with UGW (Table 4). The same trend was seen for some nutrients and compounds of the biomass, for example $\mathrm{Mg}$, $\mathrm{S}, \mathrm{P}, \mathrm{K}, \mathrm{C}$ and $\mathrm{N}$, cellulose and lignin. The nutrients which exhibited statistical difference were $\mathrm{Ca}$ and $\mathrm{Na}$, however no similarity was seen between their behaviour, with the order of losses for type of water used for irrigation being: $\quad \mathrm{UGW}=\mathrm{FPW}>\mathrm{OPW}$ and OPW=UGW $>$ FPW respectively.

Half-life was more sensitive in indicating variations in decomposition, as there were significant statistical differences for $\mathrm{Ca}, \mathrm{Mg}, \mathrm{Na}$ and biomass (Table 4). There was statistical similarity between FPW and UGW for half-life in $\mathrm{Ca}$ and $\mathrm{Mg}$, however FPW gave a greater halflife for $\mathrm{Na}$ with a shorter half-life for biomass. OPW and UGW showed similarity between $\mathrm{Na}$ and biomass for half-life, with OPW giving a shorter half-life for $\mathrm{Mg}$ and a longer half-life for $\mathrm{Ca}$.

Table.4: Loss of mass and the half-life of biomass and nutrients in sunflower shoot residues irrigated with UGW after 69 days of incubation in soil irrigated with reverse-osmosis produced water (OPW), filtered produced water (FPW) and underground water $(U G W)$ (Test 2).

\begin{tabular}{|c|c|c|c|c|c|c|c|c|c|c|c|}
\hline \multirow{2}{*}{$\begin{array}{l}\text { Type of } \\
\text { water }\end{array}$} & \multirow{2}{*}{ Biomass } & \multicolumn{10}{|c|}{ Chemical Constituent } \\
\hline & & $\mathrm{Ca}$ & $\mathrm{Mg}$ & $\mathrm{Na}$ & $\mathrm{K}$ & $\mathrm{S}$ & $\mathrm{P}$ & $\mathrm{N}$ & $\mathrm{C}$ & Cellulose & Lignin \\
\hline & \multicolumn{11}{|c|}{ Loss of mass, $\%$} \\
\hline OPW & $72.3 \mathrm{a}$ & $41.1 \mathrm{~b}$ & $51.1 \mathrm{a}$ & $85.5 \mathrm{a}$ & $97 \mathrm{a}$ & $80.6 \mathrm{a}$ & $49 a$ & $62 a$ & $76 a$ & $84 a$ & $58 \mathrm{a}$ \\
\hline FPW & $74.8 \mathrm{a}$ & $48.7 \mathrm{a}$ & $47.8 \mathrm{a}$ & $43.8 b$ & $100 \mathrm{a}$ & $82.6 \mathrm{a}$ & $41 \mathrm{a}$ & $68 \mathrm{a}$ & $84 a$ & $81 \mathrm{a}$ & $60 \mathrm{a}$ \\
\hline \multirow[t]{2}{*}{ UGW } & $72.8 \mathrm{a}$ & $52.4 \mathrm{a}$ & $38.9 \mathrm{a}$ & $77.5 \mathrm{a}$ & $98 \mathrm{a}$ & $82.2 \mathrm{a}$ & $45 \mathrm{a}$ & $62 \mathrm{a}$ & $81 \mathrm{a}$ & $82 \mathrm{a}$ & $49 a$ \\
\hline & \multicolumn{11}{|c|}{ Half-life, $t$-days } \\
\hline OPW & $36 a$ & $91 \mathrm{a}$ & $67 b$ & $20.0 \mathrm{~b}$ & $13 \mathrm{a}$ & $29 a$ & $73 a$ & $50 \mathrm{a}$ & $33 a$ & ND & ND \\
\hline FPW & $35 b$ & $72 b$ & $75 \mathrm{ab}$ & $44.3 \mathrm{a}$ & $8 \mathrm{a}$ & $27 \mathrm{a}$ & $91 \mathrm{a}$ & $43 \mathrm{a}$ & $26 a$ & ND & ND \\
\hline UGW & $37 \mathrm{a}$ & $64 b$ & $97 \mathrm{a}$ & $23.7 b$ & $13 \mathrm{a}$ & $27 \mathrm{a}$ & $80 a$ & $50 \mathrm{a}$ & $28 \mathrm{a}$ & ND & ND \\
\hline
\end{tabular}

Different lowercase letters in a column indicate differences between mean values by Tukey's test at 5\% probability. ND = Not determined.

3.4 Influence of the chemical composition of the residue on decomposition and the loss of biomass and nutrients

The loss of nutrients and organic compounds was influenced by the chemical properties of the residue under decomposition (MANOVA, $\mathrm{F}=12.85, \mathrm{R}^{2}=0.85, \mathrm{P}<0.001$ ). Considering the effect of the predictor variables group (residue composition) on the variable response group, the $\mathrm{C}: \mathrm{N}$ ratio displayed the greatest control over the loss of nutrients and organic components, as indicated by the lower lambda value (Table 5), followed by the cellulose: $\mathrm{Mg}$ ratio. The $\mathrm{C}: \mathrm{N}$ ratio influenced the loss of $\mathrm{Mg}, \mathrm{Na}, \mathrm{N}, \mathrm{S}$, biomass, lignin and cellulose, while the cellulose: $\mathrm{Mg}$ ratio affected the loss of $\mathrm{Mg}, \mathrm{Na}$, biomass and cellulose. The loss of $\mathrm{Na}$ and cellulose, and of $\mathrm{N}$ and $\mathrm{S}$, were also influenced by the ratios of cellulose: $\mathrm{N}$ and cellulose:S, respectively. 
Table.5: F-test probability and Wilks's lambda for the initial chemical characteristics of sunflower shoot residue produced with reverse-osmosis produced water (OPW), filtered produced water $(F P W)$ and underground water (UGW) on mineralisation, in soils irrigated with UGW after 69 days incubation.

\begin{tabular}{|c|c|c|c|c|c|c|c|c|c|c|c|}
\hline \multirow{3}{*}{\multicolumn{2}{|c|}{$\begin{array}{l}\text { Initial chemical } \\
\text { characteristics }^{\S} \text { Lignin }\end{array}$}} & \multicolumn{8}{|c|}{ Loss of nutrients/organic constituent } & \multirow{2}{*}{\multicolumn{2}{|c|}{$\begin{array}{l}\text { Wilks's } \\
\text { lambda }\end{array}$}} \\
\hline & & $\mathrm{Mg}$ & $\mathrm{Na}$ & $\mathrm{N}$ & $\mathrm{K}$ & $\mathrm{S}$ & Biomass & Cellulose & $\mathrm{C}$ & & \\
\hline & & \multicolumn{8}{|c|}{ F-test probabilility } & Value & $\mathrm{P}$ \\
\hline $\mathrm{C}: \mathrm{N}$ & $<0.01$ & $<0.01$ & $<0.01$ & $<0.001$ & 0.15 & $<0.001$ & $<0.001$ & $<0.01$ & $<0.10$ & 0.014 & $<0.01$ \\
\hline $\mathrm{Ca}$ & 0.16 & 0.16 & 0.15 & 0.25 & 0.88 & $<0.10$ & 0.24 & $<0.05$ & $<0.10$ & 0.10 & 0.11 \\
\hline Cellulose & 0.81 & 0.19 & 0.46 & 0.32 & 0.55 & 0.15 & $<0.10$ & 0.62 & 0.67 & 0.13 & 0.16 \\
\hline Cellulose: $\mathrm{Ca}$ & 0.87 & 0.69 & 0.41 & 0.31 & 0.62 & 0.42 & 0.27 & $<0.10$ & 0.35 & 0.27 & 0.47 \\
\hline Cellulose: $\mathrm{Mg}$ & 0.55 & $<0.05$ & $<0.05$ & 0.36 & 0.64 & 0.97 & $<0.10$ & $<0.05$ & 0.74 & 0.05 & $<0.05$ \\
\hline Cellulose:N & 0.16 & 0.84 & $<0.05$ & 0.24 & 0.34 & 0.17 & 0.44 & $<0.05$ & 0.87 & 0.07 & $<0.10$ \\
\hline Cellulose:K & 0.21 & 0.50 & 0.88 & 0.70 & 0.79 & $<0.10$ & 0.42 & $<0.05$ & 0.32 & 0.16 & 0.21 \\
\hline Cellulose:S & 0.22 & 0.86 & 0.99 & $<0.01$ & 0.77 & $<0.05$ & 0.64 & 0.27 & 0.35 & 0.10 & $<0.10$ \\
\hline Carbon & $<0.05$ & 0.53 & 0.82 & 0.26 & 0.41 & 0.15 & 0.18 & $<0.10$ & 0.99 & 0.23 & 0.37 \\
\hline
\end{tabular}

${ }^{\S}$ The remaining constituents (N, P, K, Na, S, Mg, lignin e cellulose, and the ratios of cellulose:P, cellulose: $\mathrm{Na}$, lignin: $\mathrm{Ca}$, lignin:N, lignin:P, lignin: $\mathrm{K}$, lignin: $\mathrm{Na}$, and lignin:Mg) did not affect mineralisation, according to the MANOVA test.

\section{DISCUSSION}

The composition of the treated water (FPW or OPW), may be related to changes in the levels of the same elements when also evaluated in the soil, i.e. reductions or increases in the levels of these elements in the water correspond to similar behaviour in the soil (Table 1). The change in soil properties (salinity, for example) may be associated with changes nutrients found in sunflowers tissues. Despite these variations in the soil being relatively wide for the type of water/treatment, only the levels of $\mathrm{Na}, \mathrm{Mg}$ and lignin showed significant changes in the tissue. Variations in the levels of $\mathrm{Na}$ in the different types of water used for irrigation may be associated with the different levels of $\mathrm{Na}$ [32], $\mathrm{Mg}$ [33] and lignin [34] found in the sunflower tissue. These findings also underline the efficiency of the adopted treatments, as regards the presence of elements and the effect on the soil and plants, with a clear advantage seen with OPW, where their composition displays a reduction in levels. Similar results for the influence of the type of water on the soil, and the efficiency of the wastewater treatments [35].

However, the rates for loss of mass and half-life in the residue, when compared to the overall average biomass in both tests under study, were very similar, which demonstrates that if evaluated using only biomass, control of residue decomposition should be attributed to the environment and its conditions (humidity, wind, sunlight, microbial activity, etc.). This association will be real; but it is also necessary to consider variations in the composition of plant tissue and the type of water that was used in producing the residue, since, in the two situations under study (Tests 1 and 2), there was an effect on the loss (\%) and half-lives (t) of the nutrients, and on the differences in the loss of total biomass for the residue in decomposition. These results are consistent with results obtained in previous studies [14, 18, 24], in which those authors observed that the chemical composition of the residue resulted in variations in its mineralisation.

When considering the reference conditions (UGW), changes in the residue produced with FPW were enough to increase the loss of $\mathrm{Na}$ and $\mathrm{K}$, whereas the changes that occurred in the residue from plots irrigated with OPW were enough to increase the loss of $\mathrm{Mg}$ and $\mathrm{P}$, and reduce loss of S. Compared to the residue produced with OPW, the loss of $\mathrm{Na}, \mathrm{K}, \mathrm{S}, \mathrm{N}$, and biomass was greater in residue obtained with FPW. It can therefore be demonstrated that irrigating with produced water alters the chemical composition of the sunflower, and subsequently influences mineralisation of the plant residue.

Previous studies have demonstrated the isolated effects of the initial chemical composition of plant residue on the decomposition of such components of organic residue as $\mathrm{C}$ and lignin [17, 18], and $\mathrm{Mg}, \mathrm{P}$, and $\mathrm{Na}[16,36]$, or on the ratios of $\mathrm{C}: \mathrm{N}$, lignin: $\mathrm{N}$ and lignin:P [37, 38]. In the present study, the loss of total biomass, $\mathrm{Na}, \mathrm{Mg}, \mathrm{S}, \mathrm{N}, \mathrm{C}$, cellulose and lignin was mainly influenced by the $\mathrm{C}: \mathrm{N}$ ratio. However, the ratios of cellulose:Mg, cellulose: $\mathrm{N}$ and cellulose:S also influenced decomposition of the sunflower residue (Table 5), possibly due to the decomposer organisms in the soil used the cellulose as a C source [39]. For decomposition of structural components such as cellulose, high levels of nutrients are required [17], which may explain the results found in this study, since the ratio of cellulose to nutrients affected the rate of decomposition, which did not occur when cellulose was considered in isolation. 
As demonstrated by the MANOVA analysis, the cellulose:Mg ratio was the most important in controlling the rate of decomposition of the sunflower residue than the ratios of cellulose:S and cellulose: $\mathrm{N}$, as it showed the lowest value for lambda $(\lambda=0.053, \mathrm{P}<0.05$; Table 5$)$. It is possible that the chemical fertilisation of the soil during preparation of the area met the needs for $\mathrm{N}, \mathrm{P}$ and $\mathrm{K}$ of the microorganisms in the soil, thus not depending on the nutrient content of the residue during decomposition of the organic matter. However, this relationship is not yet clear; new studies could therefore consider residues with different cellulose to nutrient ratios, in evaluating the rate of decomposition.

In contrast to results obtained in other studies [17, 18] there was no effect from lignin content on the loss of nutrients, $\mathrm{C}$, cellulose or total biomass. It is possible that the incubation period of the residue (69 days) was not sufficient for the lignin to affect decomposition, or it can be considered that interference by the lignin in the rate of decomposition only occurs after depletion of the more labile fractions of the organic residue [38].

There were similar variations in the loss of some residue components in soils irrigated with UGW and with produced water (OPW and FPW). However, irrigating the soil with OPW or FPW favoured the loss of $\mathrm{Ca}$ and $\mathrm{Mg}$ respectively. High levels of salts affect the decomposition of organic residue by reducing the size and diversity of the microbial community in the soil [22, 40-42] as well as its activity [23, 43]. But in this study, the highest values seen for $\mathrm{Na}^{+}, \mathrm{Cl}^{-}, \mathrm{HCO}_{3}$ - and $\mathrm{EC}$ with FPW (Table 1) did not reduce the loss of nutrients (except for $\mathrm{Na}$ ), biomass or other constituents of the sunflower residue. Under these conditions, it can be associate the capacity of soil microorganisms for rapid response with changes in soil salinity [21, 43]; this can be attributed to adaptation to the new conditions. Also to be considered are the joint changes in the microbial structure of the soil due to salinity and alkalinity [22] in arid soils, resulting in selection of the most efficient species for promoting decomposition of the residue. In order to clarify this issue, further studies are needed into microbial communities involved in the decomposition of residue in soils irrigated with FPW.

\section{CONCLUSIONS}

Irrigation with produced water changes the chemical characteristics of the soil and the composition of cultivated plants at a sufficient level to influence the rate of decomposition of the organic residue, these effects being variable and dependent on the type of pre-treatment used. The produced water treated by filtration favoured greater the decomposition of sunflower residue than that by reverse osmosis.
It is necessary to test new ways of treating produced water to be used in the irrigation of crops, especially processes where there is no addition of biocides, in the case of treatment by reverse osmosis, and which are effective in the removal of salts, in the case of treatment by filtration. Studies are also necessary to evaluate the cumulative effect of successive irrigation with produced water on the decomposition of residue and on the soil microbiota, as well as on the accumulation of toxic minerals in the soil.

\section{ACKNOWLEDGEMENT}

This study is part of a project into the reuse of produced water for irrigation. The authors wish to thank Petrobras for the financial and technical support, and CNPq for the scholarships granted.

\section{REFERENCES}

[1] Aceves, MB, Grace, C, Ansorena, J, Dendooven, L, Brookes PC (1999). Soil microbial biomass and organic $\mathrm{C}$ in a gradient of zinc concentrations in soils around a mine spoil tip. Soil Biol. and Biochem. 31, 867-876.

[2] Al-Haleem, AA, Abdulah, HH, Saeed, E, AbdulJalil, 2010. Components and Treatments of Oilfield Produced Water. $\quad$ Al-Khwarizmi EngineeringJournaul. 6, 24-30.

[3] Amougou, N, Bertrand, I, Machet, JM, Recous, S (2011). Quality and decomposition in soil of rhizome, root and senescent leaf from Miscanthus X Giganteus, as affected by harvest date and $\mathrm{N}$ fertilization. Plant Soil. 338, 83-97.

[4] Bhattacharya, T, Chakraborty, S, Banerjee, DK(2010). Heavy metal uptake and its effect on macronutrients, chlorophyll, protein, and peroxidase activity of Paspalumdistichumgrown on sludgedosed soils.Envir.Monit.and Assess. 169, 15-26.

[5] Birouste, M, Kazakou, E, Blanchard, A, Roumet, C(2011). Plant traits and decomposition: are the relationships for roots comparable to those for leaves? Annals of Botany 1- 10 Available online athttp://aob.oxfordjournals.org/content/early/2011/1 2/05/aob.mcr297.short.Accessed December 14, 2013.

[6] Bowles, TM, Acosta-Martínez, V, Calderón, F, Jackson, LE(2014). Soil enzyme activities, microbial communities, and carbon and nitrogen availability in organic agroecosystems across an intensivelymanaged agricultural landscape. Soil Biol.\&Biochem. 68, 252-262.

[7] Caovilla, FA, Sampaio, SC, Smanhotto, A, Nóbrega, LHP, Queiroz, MMF, Gomes, BM(2010). Características químicas de solo cultivado com soja e irrigado com água residuária da suinocultura. Rev. 
Brasileira de Engenharia Agrícola e Ambiental 14, 692-697.

[8] Castro, H,Fortunel, C, Freitas, H(2010).Effects of land abandonment on plant litter decompositionin a Montado system: relation to litter chemistryand community functional parameters. Plant and Soil. 333,181-190.

[9] Chander, K, Bookes, PC(1991). Plant inputs of carbon to metal-contaminated soil and effects on the soil microbial biomass. Soil Biol. and Biochem. 23, 116-177.

[10]Chatzakis, MK, Tzanakakis, VA, Mara, DD, Amgelakis, AN(2011). Irrigation of castor bean (Ricinuscommunis L.) and sunflower (Helianthus annus L.) plant species with municipal wastewater effluent: impacts on soil properties and seed yield. Water. 3, 1112-1127.

[11] Chowdhury, N, Marschner, P, Burns, RG (2011). Soil microbial activity and community composition: Impact of changes in matric and osmotic potential. Soil Biol.\&Biochem. 43, 1229-1236.

[12]FAO (FOOD AND AGRICULTURE ORGANIZATION)(2006). World reference base for soil resources. Rome: FAO/ISSS/ISRIC. 145 p. (FAO.World Soil Resources Reports, 103).

[13] Goebel, M, Hobbie, SE, Bulaj, B, Zadworny, M, Archibald, DD, Oleksyn, J, Reich, PB, Eissenstat, $\operatorname{DM}$ (2011). Decomposition of the finest root branching orders: linking belowground dynamics to fine-root function and structure. Ecolog.Monographs. 81, 89-102.

[14] Goering, HK, Van Soest, PJ(1975). Forage fiber analyses (Apparatus, reagents, procedures, and some applications). Washington: United States Department of Agriculture (Agriculture Handbook No. 379) 20 p.

[15] Gupta, S, Satpati, S, Nayek, S, Garai, D(2010). Effect of wastewater irrigation on vegetables in relation to bioaccumulation of heavy metals and biochemical changes.Environm.Monit.and Assess. 165, 169-177.

[16] Hagemann, M(2011). Molecular biologyof cyanobacterial salt acclimation.FEMS Microb.Reviews. 35 87-123.

[17] Il'In, VB (2007). Heavy Metals in the Soil-Crop System.Eurasian Soil Science. 40, 993-999.

[18]Lado, M, Ben-Hur, M (2009). Treated domestic sewage irrigation effects on soil hydraulic properties in arid and semiarid zones: a review. Soil and Till.Research. 106, 152-163.

[19]Lemma, B, Nilsson, I, Kleja, DB, Olsson, M, Knicker, H (2007).Decomposition and substrate quality of leaf litters and fine roots from three exotic plantations and a native forest in the southwestern highlands of Ethiopia. Soil Biol.\&Biochem. 39, 2317-2328.

[20]Liu, J, Guo, WQ, Shi, DC(2010). Seed germination, seedling survival, and physiological response of sunflowers under saline and alkaline conditions.Photosynthetica. 48, 278-286.

[21] Manzoni, S, Trofymow, JA, Jackson, RB,Porporato, $\mathrm{A}(2010)$. Stoichiometric controls on carbon, nitrogen, and phosphorus dynamics in decomposing litter. Ecolog.Monographs. 80, 89-106.

[22] Mavi, MS, Marschner, P, Chittleborough, DJ, Cox, JW, Sanderman, J (2012). Salinity and sodicity affect soil respiration and dissolved organic matter dynamics differentially in soils varying in texture. Soil Biol.\&Biochem. 45, 8-13.

[23] Medeiros, SS, Soares, AA, Ferreira, PA, Neves, JCL, Souza, JA(2008). Utilização de água residuária de origem doméstica na agricultura: estudo nutricional do cafeeiro. Rev.Brasileira de Eng.Agrícola e Ambiental. 10, 456-465.

[24] Minderman.G(1968).Addition, Decomposition and Accumulation of Organic Matter in Forests.J.of Ecol. 56, 355-362.

[25] Morugán-Coronado, A, García-Orenes, F, MataixSolera, J, Arcenegui, V, Mataix-Beneyto, J (2011). Short-term effects of treated wastewater irrigation on Mediterranean sunflower seedlings and analysis of their stress factors. Environm. and Experim. Botany. 54, 8-21.

[26] Nascimento, JF, Pereira Jr., OA, Melo, MV, Boges, CP, Nóbrega, R. (Report); Santos NOF dos (Participant) (2006) Tratamento de águas de produção para uso em irrigação. Tecnologia de Processamento Primário e Avaliação de Petróleos/CENPS-PDP (Final Report) 57p.

[27] Osono, T, Takeda, H(2004). Accumulation and release of nitrogen and phosphorus in relation to lignin decomposition in leaf litter of 14 tree species. Ecolog.Research.19, 593-602.

[28]R Core Team (2013).R: A Language and Environment for Statistical Computing.R Foundation for Statistical Computing.Vienna, Austria. Disponívelem: http://www.R-project.org.

[29] Ranjbar, F, Jalali, M(2012). Calcium, magnesium, sodium, and potassium release during decomposition of some organic residues. Communic.in Soil Scien.and Plant Anal. 43, 645-659.

[30] Rezende, CP, Cantarutti, RB, Braga, JM, Gomide, JA, Pereira, JM, Ferreira, E, Terré, R, Macedo, R, Alves, BJR, Urquiaga, S, Cadisch, G, Giller, KE, Boddey, RM (1999). Litter deposition and disappearance in Brachiaria pastures in Atlantic 
forest region of South Bahia, Brazil. Nut.Cycl.in Agroecos. 54, 99-112.

[31] Rietz, DN, Haynes, RJ(2003). Effects of irrigationinduced salinity and sodicity on soil microbial activity.Soil Biol.\&Biochem. 35, 845-854.

[32] Sandri, D, Matusura, EE, Testezlaf, R (2006). Teores de nutrientes na alface irrigada com água residuária aplicada por sistema de irrigação. Engenharia Agrícola Jaboticabal. 26, 45-57.

[33] Shahbaz, M, Ashraf, M, Akram, NA, Hanif, A, Hameed, S, Joham, S, Rehmanet, R (2011). Saltinduced modulation in growth, photosynthetic capacity, proline content and ion accumulation in sunflower (Helianthus annuus L.).Acta Physiol. Plant., Poland, v. 33, n. 4, p. 1113-1122, jul. 2011.

[34] Sharma, RK, Agrawal, M, Marshal, F(2007). Heavy metal contamination of soil and vegetables in suburban areas of Varanasi, India.Ecotox. and Environm. Safety. 66, 258-266.

[35] Silva FC(2009). Manual de análises químicas de solos, plantas e fertilizantes. 2. ed. Brasília, DF, EMBRAPA. 627p.

[36] Silver, WL, Miya, RK(2001).Global patterns in root decomposition: comparisons of climate and litter quality effects. Oecologia. 129, 407-419.

[37] Talbot, JM, Treseder, KK(2012). Interactions among lignin, cellulose, and nitrogen drive litter chemistrydecay relationships. Ecology. 93, 345-354.

[38] Thomas, RJ, Asakawa, NM(1993). Decomposition of leaf litter from tropical forage grasses and legumes.Soil Biol. and Biochem. 25, 1351-1361.

[39] Wang, L-W, Showalter, AM, Ungar IA (1997). Effect of salinity on growth, ion content, and cell wall chemistry in Atriplexprostrata (Chenopodiaceae).American J. of Bot. 84, 12471255.

[40] Uselman, SM, Qualls, RG, Lilienfein, J (2012). Quality of soluble organic C, N, and P produced by different types and species of litter: Root litter versus leaf litter. Soil Biol.\&Biochem. 54, 57-67.

[41] Yan, N, Marschner, P(2013). Response of soil respiration and microbial biomass to changing EC in saline soils. Soil Biology \& Biochemitry. 65, 322328.

[42] Yeomans, J.C., Bremner, J.M., 1988. A rapid and precise method for routine determination of organic carbon in soil. Communications in Soil Sc. and Plant Analysis. 19, 1467-1476.

[43] Yuan, BC, Xu, XG, Li, ZZ, Gao, TP, Gao, M, Fan, XW, Deng, JM(2007). Microbial biomass and activity in alkalized magnesic soils under arid conditions. Soil Biol. \& Biochem. 39, 3004-3013. 